1-1-1909

\title{
Some Factors Influencing the Vigor of Incubator Chickens
}

\author{
J. H. Stewart \\ Horace Atwood
}

Follow this and additional works at: https://researchrepository.wvu.edu/ wv_agricultural_and_forestry_experiment_station_bulletins

\section{Digital Commons Citation}

Stewart, J. H. and Atwood, Horace, "Some Factors Influencing the Vigor of Incubator Chickens" (1909). West Virginia Agricultural and Forestry Experiment Station Bulletins. 124.

https://researchrepository.wvu.edu/wv_agricultural_and_forestry_experiment_station_bulletins/124 @ WVU. It has been accepted for inclusion in West Virginia Agricultural and Forestry Experiment Station Bulletins by an authorized administrator of The Research Repository @ WVU. For more information, please contact ian.harmon@mail.wvu.edu. 

WEST VIRGINIA UNIVERSITY

AGRICULTURAL EXPERIMENT STATION

MORGANTOWN, W. VA.

\section{Some Factors Influencing the Vigor of Incubator Chickens}

1. Age and Vigor of Parent Stock

2. Cooling Eggs During Incubation

3. The Use of Moisture

J. H. StFwak' A ANd Horace Atwood

[The Bulletins and Reports of this Station will be mailed free to any citizen of West Virginia upon written application. Address Director of Agricultural Experiment Station, Morgantown, W. Va.] 
Hon. M. P. Shawkey,............... Charleston, W. Va. Hon. J. B. Finley.................Parkersburg, W. Va. Hon. George S. Latdley............... Charleston, W. Va. Hon. G. A. NоRтнсотт................ Huntington, W. Va. Hon. M. C. LoUGH................... Fairmont, W. Va. President of the Board of Regents........M. P. SHAWKeY. Treasurer THOMAS E. Hodges

THE BOARD OF CONTROL.

Hon. James F. Lakin.................. Charleston, W. Va. Hon. John A. SHeppard................ Charleston, W. Va. Hon. Thomas E. Hodges................. Charleston, W. Va.

\section{STATION STAFF.}

James H. Stemart, A. M........ Director and Agriculturist Bert H. Hite, M. S............. Vice Director and Chemist W. M. Munson, Рн. D ................ Horticulturist W. E. Rumsey, B. S. AGr................ Entomologist

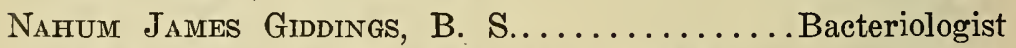
HoraCe Atwood, M. S. AđR, .......... Assistant Agriculturist Fred E. Brooks................... Associate Entomologist Frank B. Kunst, A. B................ Assistant Chemist Chas. E. Weaklex, Jr.................. Assistant Chemist J. H. Berghuis Krak.................. Assistant Chemist A. L. DACY, B. Sc.............. Assistant Horticulturist

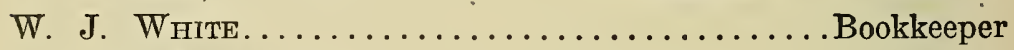
M. A. Stewart...........................Librarian Alice Engle......................................... B. D. Wніте............................. Herdsman

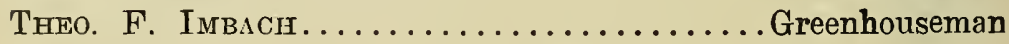




\section{A Few Preliminary Experiments on the Effect of the Age of the Parents Upon the Vigor of Chickens.}

Early hatched pullets lay better in winter, when eggs are high in price, than old hens, and as a consequence on many egg farms practically all of the older hens are disposed of each summer and their place is taken by pullets hatched during the preceding spring. While this undoubtedly is good policy from the standpoint of winter egg production, yet it has led in many cases into the practice of incubating the eggs of these pullets, during the following spring, when the fowls are practically one year old. Is it a good plan to use such eggs for hatching? Are the resulting chicks strong and hearty, and do they develop into as thrifty, vigorous individuals as though they were the offspring of more mature stock? The experiments described below have been performed to throw light on this question.

\section{TEST 1.}

In this experiment three pens of single comb White Leghorns were used. Pen 1 consisted of pullets; pen 2 consisted of hens two years old; and pen 3 consisted of hens three years old. They were of the same strain, and were fed and handled in the same manner. The cocks which were mated with them were alternately placed in the different pens so as to eliminate any possible effect resulting from the individuality of the males. The three year old hens had been selected with particular reference to size and apparent vigor.

The following table shows the number of eggs incubated from each lot of fowls, the weight of the eggs, the weight of the shickens when removed from the incubator, and other de- 
tails of the test. The eggs were hatched in one incubator and the chicks kept separate at hatching time by means of "pedigree trays."

\section{Cyphers incubator, started June 3, 1907.}

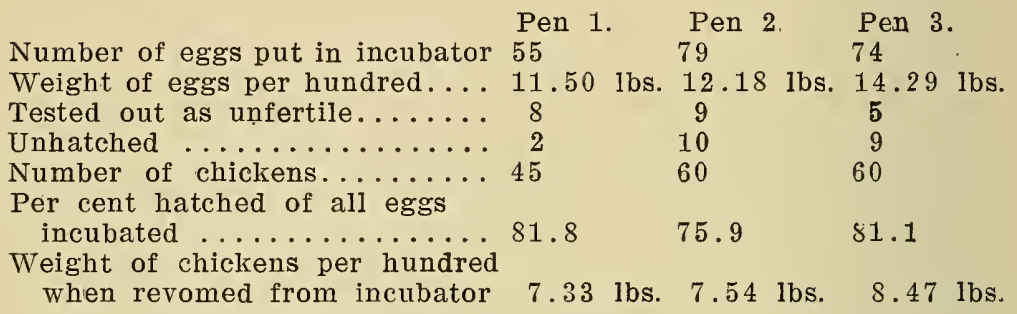

The eggs from the hens three years old were heavier, and the chickens were heavier than in the case of the younger fowls.

The chickens were placed in "Universal Hovers" and fed and treated as nearly alike as possible. An accident caused this experiment to terminate July $6 \mathrm{th}$. Up to that time there had died 21 chickens hatched from eggs laid by pullets, 8 chickens from eggs laid by hens two years old, and 6 whickens hatched from eggs laid by hens three years old. Most of these deaths seemed to be due to digestive troubles.

In this test, then, the eggs laid by hens three years old were more satisfactory for hatching than those laid by the younger fowls for the chicks were heavier, and much mize vigorous than the chickens hatched from pullet eggs, and apparently somewhat more vigorous than the chicks hatched from eggs laid by hens two years old. There was not much difference in the hatchability of the eggs.

The following table shows the details of the second test. 
TEST 2.

Cyphers Incubator, started June 19, 1907.

Number of eggs put in

$$
\text { Pen 1. Pen 2. Pen 3. }
$$

incubator ...............114 $92 \quad 88$

Weight of eggs per hundred.... 11.71 1bs. 12.22 lbs. 13.16 lbs.

Tested out July 4 th as infertile. . $19 \quad 15 \quad 9$

Cracked in turning and removed none 4

Number of chickens........ $76 \quad 62 \quad 64$

Percentage hatched of all eggs

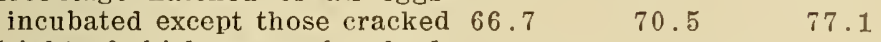

Weight of chickens per hundred when removed from incubator $7.64 \mathrm{lbs} .7 .75 \mathrm{lbs} . \quad 8.501 \mathrm{bs}$.

Number of deaths during first

two weeks ............ $12 \quad 7$

Weight of chickens when forty

days old, per hundred....2.24.7 lbs. 27.6 lbs. 35.0 lbs.

In this test the oldest hens laid egg's that hatched out more, heavier and stronger chickens than in the case of the younger hens. The growth of the chickens was slow, due partly at least to the heat of summer, but the chickens from the three year old hens were materially heavier than the others when forty days old.

\section{TEST 3.}

Eggs incubated in Prairie State Incubator, started Sept. 5, 1907.

\begin{tabular}{|c|c|c|c|}
\hline umber of eggs put in incubator. & $\begin{array}{l}\text { Pen } 1 . \\
.71\end{array}$ & $\begin{array}{c}\text { Pen } 2 . \\
55\end{array}$ & $\begin{array}{l}\text { Pen } 3 . \\
57\end{array}$ \\
\hline Teight of eggs per hundred. & $12.21 \mathrm{lbs}$. & $12.04 \mathrm{lbs}$. & $13.071 \mathrm{bs}$ \\
\hline Tested out unfertile Sept. 17th.. & . 18 & 7 & 8 \\
\hline umber of chickens ....... & . 51 & 46 & 39 \\
\hline ercentage hatched of all & & & \\
\hline eggs incubated ......... & 71.8 & 83.6 & 68.4 \\
\hline eight of chickens when removed & 8 & & \\
\hline $\begin{array}{l}\text { from incubator, per hundred... } \\
\text { umber of deaths during first }\end{array}$ & $7.64 \mathrm{lbs}$. & $7.71 \mathrm{lbs}$. & 8.0 \\
\hline zs ........... & 5 & 1 & 3 \\
\hline
\end{tabular}

The chickens were brooded in "Universal Hovers" in adjoining colony houses, and through an oversight they became mixed together when four weeks of age, making it impossibe 
to obtain the weight of each lot of chickens and the experiment was discontinued.

In this test also the eggs laid by the oldest hens were largest and hatched out the heaviest chickens. The best hatch was obtained from the eggs laid by the two year old hens. The death losses were low with a possible exception in the case of the chicks hatched from eggs laid by the youngest fowls, but with this lot of chickens the five deaths recorded may have been due to the chickens catching cold, as four or five chickens in this lot were found by the attendant huddled together one morning outside the brooder, where they probably had remained for sometime in the cold.

\section{TEST 4.}

This test was begun April 20, 1908, and a Cyphers Incubator was used for hatching the eggs. Eggs from three lots of Single Comb White Leghorn fowls of the same strain were employed. Lot 1 consisted of pullets and cockerels hatched October 14, 1907, making these fowls practically six months old when the eggs were laid that were used in this test. Lots 2 and 3 consisted of three year old fowls of superior size and vigor. Lot 2 had been kept in a fresh air house during the winter of 1907-8, and they had not been fed for egg production, while lot 3 , on the other hand, had been wintered in a warmer house and had been fed heavily for the production of eggs.

The following table shows the details of the test.

\begin{tabular}{|c|c|c|c|c|}
\hline $\begin{array}{l}\text { Number of eggs incubated...... } \\
\text { Weight of eggs per hundred.... } \\
\text { Tested out May } 4 \text { th as unfertile.. } \\
\text { Cracked in turning........... }\end{array}$ & $\begin{array}{l}\text { Pen } 1 . \\
104 \\
9.95 \text { lbs. } \\
28 \\
1\end{array}$ & $\begin{array}{l}\text { Pen } \\
72 \\
13.5 \\
8 \\
3\end{array}$ & lbs. & $\begin{array}{l}\text { Pen } \\
72 \\
13.3 \\
36 \\
2\end{array}$ \\
\hline $\begin{array}{l}\text { Number of chickens............. } \\
\text { Per cent hatched of all eggs incu- }\end{array}$ & 69 & & 86 & \\
\hline $\begin{array}{l}\text { bated except those cracked.... } \\
\text { eight of chickens per hundred }\end{array}$ & 66.99 & & 61.87 & \\
\hline $\begin{array}{l}\text { when removed from incubator. } \\
\text { Veight of chicks per hundred }\end{array}$ & $6.46 \mathrm{lbs}$. & & 9.17 & 7 lbs. \\
\hline $\begin{array}{l}\text { when forty-six days old....... } \\
\text { umber of chickens died in first }\end{array}$ & 30.74 lbs. & & 37.32 & $2 \mathrm{lbs}$. \\
\hline forty-six days $\ldots \ldots \ldots \ldots \ldots$ & 10 & & 2 & \\
\hline
\end{tabular}


In this test also the older fowls laid eggs that were larger and which hatched out larger and stronger chicks than was the case with the younger, less mature fowls. The heavy :"ceding for egg production which pen three received during the winter apparently affected the fertility of the eggs, as there $W^{\prime}{ }^{\prime} \mathrm{e}$ more than four times as many unfertile eggs from this lot oi fowls as from the other lot of three year old hens that had not been forced for egg production during the winter.

\section{TEST 5.}

This test was begun March 23, 1909. The eggs were hatched in a Model incubator equipped with a moisture regulator. Eggs from two lots of White Leghorn fowls were employed. Lot 1 consisted of hens three years old that had been kept during the winter in an open shed and fed entirely upon whole grain. On account of their age, method of feeding, and their cold quarters there was practically no egg production from these fowls from the beginning of moult until the latter part of February. The fowls in this flock numbered about one hundred, and they had been selected from a larger fock on account of their size, and apparently vigorous constitutions. During the winter preceding this test they were perfectly healthy, no colds, roup, or other disturbance having been noticed. With this flock of hens there had been placed earlier in the season five cockerels and one cock three years old. The fowls were allowed free range. The second lot of fowls were practically six months old at the beginning of the experiment and they were mated with cockerels of the same age.

The following table gives the details of the test.

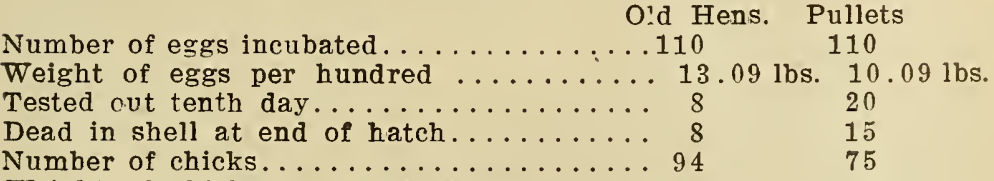

Weight of chicks per hundred when

removed from incubator.......... 8.24 lbs. $6.51 \mathrm{lbs}$.

Weight per hundred when 22 days old ...... $25.17 \mathrm{lbs} .18 .31 \mathrm{lbs}$.

Deaths from all causes during first 22 days. . 116 
In this test the old hens laid eggs which were larger and hatched better, and the chicks were larger, stronger and grew faster than was the case with the chicks hatched from eggs laid by the younger fowls.

\section{TEST 6.}

This test was begun April 5, 1909. Eggs were used from the same fowls as in the preceding test. The eggs from both lots of fowls were hatched in a $360 \mathrm{Egg}$ Cyphers Incubator.

The following table gives the details of this test.

Old Hens. Pullets

Number of eggs incubated ...........180

180

Weight of eggs per hundred.......... $13.04 \mathrm{lbs} .10 .30 \mathrm{lbs}$.

Cracked in turning ............... 2

Tested out April 15th............. 12 22

Dead in shell at end of hatch......... $14 \quad 30$

Number of chicks ..............152 127

Weight of chicks per hundred when

removed from incubator .......... $9.15 \mathrm{lbs} .6 .75 \mathrm{lbs}$.

Deaths from all causes during first

three weeks ................... $3 \quad 14$

Weight of chicks per hundred

three weeks old $\ldots \ldots \ldots \ldots \ldots \ldots 25.4 \mathrm{lbs} . \quad 19.0 \mathrm{lbs}$.

In all essential features this test is in accord with the preceding one, as the chicks from the old hens were larger and. stronger than the others.

\section{TEST 7.}

In this test eggs were incubated from the three year old hens already mentioned and from pullets hatched early in the spring of 1908. During the winter of 1908-9 these pullets had been fed liberally for egg production and at the beginning of the test they had been laying heavily for six months.

The following table gives the details of this test, which was begun April 14, 1909. 
Incubator used-Cornell. 120-egg sizc.

Old Hens. Young Fowls.

Number of eggs incubated...........660 $60 \quad 60$

Weight of eggs per hundred..........13.2 lbs. 11.7 lbs.

Tested out April 30 th............... $9 . \ldots \ldots$

Total number of chicks.............. $39 \quad 25$

Weight of chicks per hundred when

removed from incubator........... $8.33 \mathrm{lbs} .7 .00 \mathrm{lbs}$.

Total died in 26 days............... 2

Weight of chicks per hundred when

26 days old ................ 26.9 lbs. 22.6 lbs.

In this test also the chicks hatched from eggs laid by old hens hatched better and they were larger, stronger and grew faster than the chicks hatched from eggs laid by the younger fowls.

\section{TEST 8.}

In this test eggs were incubated from the same hens as in the preceding test.

The following table gives the details of this experiment which was begun May 22, 1909.

\section{Incubator used-Cyphers, 360-egg size.}

Old Fowls. Young Fowls.

Number of eggs incubated.................. 180

Weight of eggs per hundred.............. $12.5 \mathrm{lbs} .12 .1 \mathrm{lbs}$.

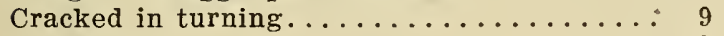

Unfertile .......................... 19

Dead in shell at end of hatch......... 14

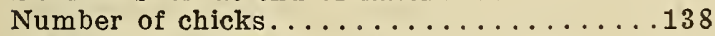

$1 \frac{1}{8}$

8

123

Weight of chicks when removed from

incubator per hundred........... $8.24 \mathrm{lbs} .7 .68 \mathrm{lbs}$.

Total deaths in 21 days............. 6

The chicks in this test were brooded in a Cornell University gasoline brooder, and they were allowed free range. When they were weighed on the 21st day it was found that a considerable number of them were missing, having been killed by cats or rats, consequently the comparative weights of the two lots of chicks 
could not be determined. The figures showing the "total deaths" represent the number of chicks that died in the brooder, and probably represents quite aceurately the comparative vigor of the two lots of ehiekens.

\section{SUMMARY.}

The following table summarizes the results of the eight experiments.

Total number of eggs incubated

Old Hens. Pullets.

less those cracked in turning.........1094

Average weight of eggs per hundred.... $12.96 \mathrm{lbs} .11 .19 \mathrm{lbs}$.

Total number of chicks........... $840 \quad 591$

Per cent hatched of eggs incubated..... $76.7 \quad 67.8$

Average weight of chicks per hundred

when removed from incubator...... $8.28 \mathrm{lbs} .7 .12 \mathrm{lbs}$.

Average weight of chicks at second

weighing, per hundred.......... $29.56 \mathrm{lbs} .23 .07 \mathrm{lbs}$.

Total number of recorded deaths....... $42 \quad 85$

Per cent of chicks which died....... 5 5 14.5

The results of this series of experiments elearly show that it is a matter of prime importance to have the breeding stoek vigorous and of mature age. The eggs from the voung fowls were smaller than the eggs from the older hens, and the chicks were smaller when they were hatehed, grew more slowly, and more of them died from chick diseases than was the case with chicks hatched from eggs laid by the mature fowls.

\section{AIRING AND COOLING EGGS DURING INCUBATION.}

Eggs hatched under natural conditions are left unprotected when the broody hen leaves the nest in search of food. At such times the eggs beeome cool or even cold, and being freely exposed to the air the absorption of oxygen and the excretion of carbon dioxide is facilitated. In the popular mind this proeess of cooling and airing is associated with the development of strong vigorous ehicks, and consequently it is not surprising 
to find many incubator manufacturers giviug directions in regard to cooling and airing eggs during the process of incubation. 'There is, however', a general lack of specifie instructions or advice as to how long to cool the eggs or how cold to allow them to become.

In the case of natural incubation it would secm that the process of eooling and airing is due to the neeessity of the mother hen of obtaining food, and may liave no connection whatever with normal incubation. Instead of being of benefit the eooling of eggs during ineubation may be detrimental in as mueh as eooling the eggs tends to slow down the vital processes and delays the development of the embryos.

In the case of machines in which the ventilation is imperfect it is quite possible that the cooling and airing process may be of benefit by giving the embryos fresh air rather than through the cooling effect, although it must be admitted that merely the eooling of the eggs may be the means of giving the embryos an increased supply of oxygen, for, when an egg is cooled the heated air in the air cell contracts and a small amount of air is drawn in through the pores of the shell.

The experiments described below have been carried out in order to determine if possible whether eggs should be cooled and aired during ineubation, and if so the reason or reasons for the beneficial effects observed.

The tests were earried out in a well lighted and well ventilated incubator room, the lower four feet of which are below the level of the ground. The side walls to that height are of eement, and above the eement walls are windows which are kept open thus allowing the wind to blow directly across the room. The temperature prevailing during the hatches was recorded by maximum and minimum thermometers located a short distance from the incubator room, and while the temperature of the room would searcely fluetuate so widely as the temperature outside, yet these temperatures are suitable for making a comparison of the conditions prevailing when the different hatehes were made. 
TEST 1.

This experiment was begun August 17, 1908. 'I'wo 360 egg Cyphers incubators were used in which to hatch the eggs and the chicks were brooded in two Cornell University gasoline brooders. White Leghorn eggs from a large flock were used and they were carefully selected so as to make the eggs in the two incubators as similar as possible. The two incubators were operated as is customary, the eggs being turned by hand twice each day and removed from the incubator chamber at each turning. The regulators were so adjusted as to hold the temperature at 102 1-2 degrees during the first half of the hatch and at 103 degrees during the latter half. The ventilators were kept open during the entire hatch.

Beginning on the second day of incubation and continuing until the nineteenth day the trays of eggs of one of the machines were removed from the incubator and covered with a thick woolen cloth and cooled as is shown in the following table. The temperature of the eggs was taken by a thermometer resting upon the eggs and covered by the blanket.

\section{AIRING EGGS IN MACHINE NO. 1.}

Eggs left out of the machine in the morning and covered with a woolen blanket for times specified.

\begin{tabular}{|c|c|c|c|c|c|c|c|c|}
\hline & & $\begin{array}{l}\text { emper } \\
\text { num. }\end{array}$ & $\begin{array}{l}\text { re of the } \\
\text { imum. }\end{array}$ & $\begin{array}{l}\operatorname{lir}_{t} \\
6 \text { P. I }\end{array}$ & $\begin{array}{l}\text { n began } \\
\text { air. }\end{array}$ & $\begin{array}{c}\text { When put } \\
\text { back. }\end{array}$ & $\begin{array}{l}\text { Minutes } \\
\text { aired, }\end{array}$ & $\begin{array}{c}\text { Cooled } \\
\text { to }\end{array}$ \\
\hline \multirow[t]{4}{*}{ Aug. } & 19. & 85 & 55 & 81 & $6: 40$ & $7: 40$ & 60 & 80 \\
\hline & 20. & 82 & 53 & 67 & $6: 30$ & $8: 30$ & 120 & 82 \\
\hline & 21. & 84 & 49 & 73 & $6: 20$ & $8: 45$ & 145 & 84 \\
\hline & 22. & 78 & 65 & 74 & $6: 35$ & $9: 00$ & 145 & 85 \\
\hline \multirow[t]{9}{*}{ i } & 23. & 78 & 58 & 71 & $6: 50$ & $9: 00$ & 130 & 83 \\
\hline & 24. & 77 & 48 & 70 & $6: 15$ & $8: 15$ & 120 & 82 \\
\hline & 25. & 72 & 59 & 80 & $6: 15$ & $8: 15$ & 120 & 82 \\
\hline & 26. & 70 & 55 & 59 & $6: 20$ & $8: 15$ & 115 & 82 \\
\hline & 27. & . & . & . & $6: 30$ & $9: 00$ & 150 & 84 \\
\hline & 28 & 74 & 50 & 67 & $6: 30$ & $9: 10$ & 160 & 83 \\
\hline & 29. & 80 & 56 & 66 & $6: 10$ & $9: 30$ & 200 & 88 \\
\hline & 30 . & 83 & 52 & 68 & $6: 45$ & $9: 30$ & 165 & 88 \\
\hline & 31. & 88 & 53 & 74 & $6: 15$ & $9: 40$ & 205 & 92 \\
\hline \multirow[t]{5}{*}{ Sept. } & 1. & 90 & 58 & 85 & $6: 00$ & $9: 00$ & 180 & 88 \\
\hline & 2. & 86 & 63 & 71 & $6: 00$ & $8: 45$ & 165 & 89 \\
\hline & 3. & 74 & 44 & 69 & $6: 00$ & $9: 15$ & 195 & 86 \\
\hline & 4. & 83 & 49 & 75 & $6: 20$ & $9: 45$ & 205 & 85 \\
\hline & 5. & 76 & 63 & 68 & $6: 20$ & $8: 55$ & 165 & 88 \\
\hline \multicolumn{2}{|c|}{ Average } & 80 & 54.7 & 71.6 & & & 152.5 & 85 \\
\hline
\end{tabular}


Although both machines were operated at the same temperature the cooled eggs hatched about twenty-four hours later than the others or practically on the twenty-second day.

The following table gives the details of the hatch.

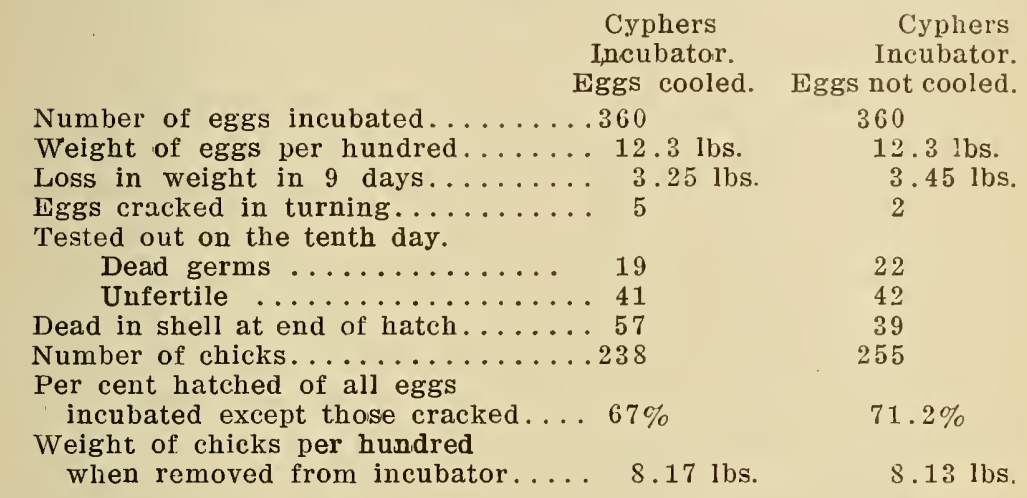

When removed from the incubator the chickens were marked and one-half of them from each machine were placed in each of two gasoline brooders. The chickens from both incubators being mixed together were subjected to the same conditions as to food and temperature. The brooding experiment was terminated September 28th, or when the chickens were three weeks old. Up to that time there had died sixteen chickens from the lot hatched from eggs that were not cooled, and eighteen clickens from the cooled eggs. Most of these deaths seemed to be due to digestive troubles, or non-absorption of the yolk sack.

When three weeks old the chickens from the cooled eggs weighed 14.7 pounds per hundred chickens, while the chicks from eggs not cooled weighed 16.8 pounds per hundred.

Result of test.-In this experiment a better hatch was obtained from the eggs not cooled, and slightly less of the chickens from the eggs not cooled died during the first three weeks, and they averaged somewhat heavier at the expiration of that time than the chicks from the cooled eggs. 


\section{'TEST' 2.}

This test was begun March 12, 1909. A three-hundred and sixty egg size Cyphers incubator was used having two trays. One tray was cooled as shown below, while the other tray was cooled no longer than was necessary when it was removed from the incubator for turning the eggs.

The incubator was operated in the usual manner, the eggs being turned twice per day. The hatehing of the cooled eggs was delayed by the cooling about twenty-four hours. The eggs not cooled hatched promptly on time. When the eggs began to pip one tray was removed to another incubator so as to keep the chicks from the two trays apart so that they could be marked. After the chicks were marked they were placed together in a Cornell University gasoline brooder. The following table shows the details of the hatch.

Cyphers incubator started March 12, 1909. One tray cooled and aired. The other not cooled. Ventilators were closed until beginning of hatch then they were left open. The lower felt diaphragm was not used.

Tray No. 1. Cooled.

Put in incubator............180 eggs.

Weight of eggs per hundred...... $12.9 \mathrm{lbs}$.

Loss in weight in 19 days........ $3.22 \mathrm{lbs}$.

Normal loss as calculated........ 3.68

Eggs cracked in turning......... 5

Unfertile eggs .............. 20

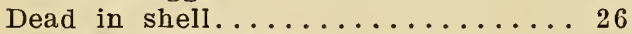

Number of chickens............. 129

Weight of chicks per hundred

when removed from incubator... 8.33 Ibs.

Weight of chicks 3 weeks old..... 23.81 lbs.

Total deaths during first 3 weeks.... 13
Tray No. 2. Not cooled.

180 eggs. $12.9 \mathrm{lbs}$. $3.30 \mathrm{lbs}$. 3.68 1 18 16 145

$7.85 \mathrm{lbs}$. $25.9 \mathrm{lbs}$.

2

Cooling was begun on the fourth day of the hatch. The tray of eggs was removed from the incubator and covered while outside the incubator with a thick woolen cloth so as to make the ehange of temperature gradual. A thermometer was 
laid on the egrgs and covered by the eloth. "The reading of the thermometer at the close of each cooling period is shown in the last column of the following table:

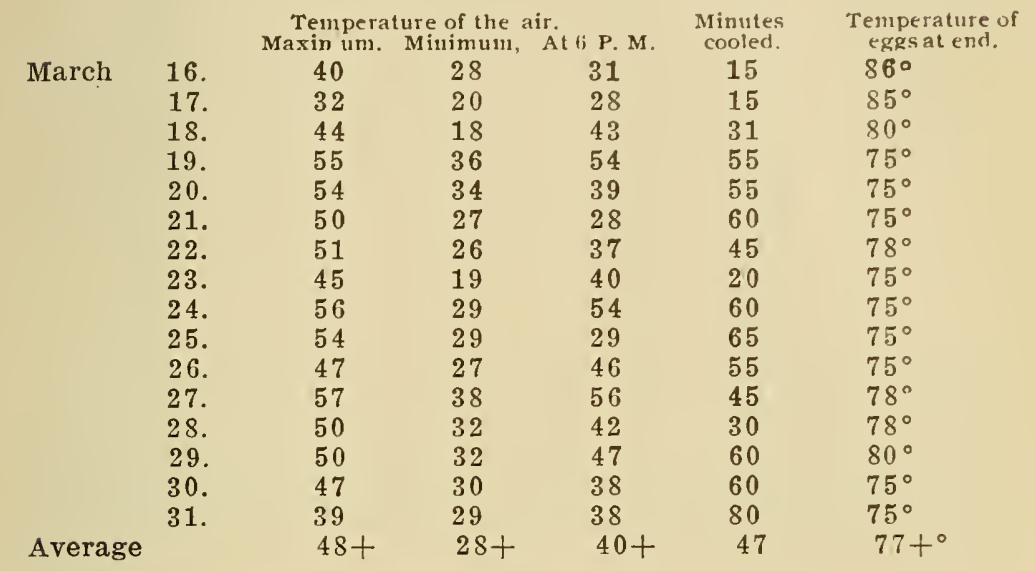

Result of the test. The eggs not cooled hatched better and the chickens were healthier and grew faster than the chickens from the cooled eggs.

\section{TEST 3.}

This test was begun May, 23, 1909. A 360-egg size Cyphers incubator was used, and the experiment was carried on in the same way as the preceding one. Cooling was begun on the fourth day and was continued as shown in the following table. The eggs were not covered while cooling. 


\begin{tabular}{|c|c|c|c|c|c|c|}
\hline & & Temp & ature of the & & Minutes & Temperature of \\
\hline May & & Maximum. & Minimum, & At 6 P. M. & cooled. & eggs at end. \\
\hline may & $2 \%$ & 78 & 60 & 65 & 16 & $88^{\circ}$ \\
\hline & 28. & 69 & 58 & 66 & 24 & $90^{\circ}$ \\
\hline & 29. & 77 & 56 & 75 & 18 & $88^{\circ}$ \\
\hline & 30. & 80 & 48 & 65 & 13 & $90^{\circ}$ \\
\hline & 31. & 83 & 58 & 79 & 20 & $92^{\circ}$ \\
\hline June & 1. & 82 & 62 & 67 & 20 & $92^{\circ}$ \\
\hline & 2. & 80 & 58 & 71 & 17 & $90^{\circ}$ \\
\hline & 3. & 75 & 62 & 73 & 20 & $90^{\circ}$ \\
\hline & 4. & 79 & 65 & 73 & 17 & $92^{\circ}$ \\
\hline & 5. & 73 & 60 & 70 & 20 & $92^{\circ}$ \\
\hline & 6. & 78 & 60 & 75 & 28 & $90^{\circ}$ \\
\hline & 7. & 81 & 56 & 78 & 25 & $92^{\circ}$ \\
\hline & 8. & 79 & 63 & 63 & 20 & $94^{\circ}$ \\
\hline & 9. & 77 & 60 & 73 & 15 & $96^{\circ}$ \\
\hline & 10. & 76 & 65 & 71 & 16 & $94^{\circ}$ \\
\hline & 11. & 75 & 68 & 70 & 16 & $94^{\circ}$ \\
\hline & 12. & 79 & 53 & 71 & 15 & $94^{\circ}$ \\
\hline Avera & & $77+$ & $59+$ & $71-$ & $19-$ & $91+$ \\
\hline
\end{tabular}

The following table shows the details of the experiment. The bottom ventilators remained closed until the beginning of the hatch. Then they were opened.

Eggs cooled. Eggs not cooled.

Number of eggs incubated..................

Weight of 180 eggs............ $21.32 \mathrm{lbs}$.

Cracked in turning............. 2

Weight of eggs June 6 th.......... $19.05 \mathrm{lbs}$.

Unfertile .................... 27

Dead in shell at end of hatch..... 17

Number of chicks.............134

Weight of chicks per hundred

when removed from incubator.... $7.87 \mathrm{lbs}$.

Weight of chicks per hundred

when 16 days old............ $13.0 \mathrm{lbs}$.

Total deaths during first 16 days... 4

180

$21.47 \mathrm{lbs}$.

4

$19.25 \mathrm{Ibs}$.

25

14

137

7.94 lbs.

12.4 lbs.

13

\section{TEST 4.}

This experiment was begun May 25, 1909. A Cyphers incubator was employed, and the eggs were cooled and the work carried on similar to the preceding test.

The following table gives the details of the hatch. 
Eggs cooled.

Number of eggs incubated.........180

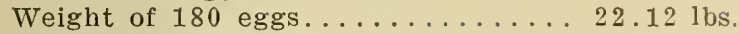

Cracked in turning............ 3

Weight of eggs June $6 \mathrm{th} \ldots \ldots \ldots .20 .12$ lbs.

Unfertile ................. 42

Dead in shell at end of hatch..... 19

Number of chicks.............116

Weight of chicks per hundred

when removed from incubator.... $8.18 \mathrm{lbs}$.

Weight per hundred when 14

days old ................ 13.3 Ibs.

Total deaths during first 14 days.... 1
Eggs not cooled.

180

$22.0 \mathrm{~s}$ lbs. 5

$20.25 \mathrm{lbs}$.

34

13

128

8.02 Ibs.

$13.4 \mathrm{lbs}$.

9

\section{TEST 5.}

This test was begun May 25, 1909, and was carried on in the same way as the two preceding tests. A 1908-model Prairie State Incubator was used. The side ventilator remained closed during the hatch. The table below shows the details of the test.

Eggs cooled. Eggs not cooled.

Number of eggs incubated.......180

Weight of 180 eggs........... $22.12 \mathrm{lbs}$.

180

Weight of eggs June 6 th...... 20.77 lbs.

Cracked in turning ............ 3

Unfertile $\ldots \ldots \ldots \ldots \ldots \ldots \ldots . \ldots 22$

Dead in shell .............. 12

Number of chicks.............143

Weight of chicks per hundred when

removed from incubator......... 8.08 lbs.

Weight of chicks when 14 days old.. 12.4 lbs.

Total deaths during first 14 days.. 1

$22.12 \mathrm{lbs}$.

$20.86 \mathrm{lbs}$.

none

38

18

124

$8.47 \mathrm{lbs}$. $13.1 \mathrm{lbs}$.

9

\section{SUMMARY.}

In the first trial with the ventilators open and with an average maximum and minimum outside temperature of $80^{\circ}$ and $54.7^{\circ}$, respectively, a better hatch was obtained, and the chicks were stronger when the eggs were not cooled.

In the second trial with closed ventilators, and with a low external temperature, the eggs not cooled hatched better and 
the chicks were stronger than was the case with the other treatment.

In tests 3,4 , and 5, conducted simultaneously, with closed ventilators, and a high outside temperature, the eggs not cooled hatched better than the cooled eggs in the two Cyphers incubators, and not quite so well in the Prairie State. The chicks, however, from the cooled eggs were materially stronger than the others in all three hatches, as fewer of them died. This would seem to indicate that in warm weather when the circulation of air in the incubator tends to become sluggish, and especially with an insufficient opening of the ventilators, it may be advisable to air the eggs for a reasonable length of time for the purpose of giving the embryos a more aderquate supply of oxygen.

It is difficult to conceive of any valid reason for cooling eggs during incubation and thus slowing down the vital processes, and these experiments seem to indicate that the beneficial effects which unquestionably sometimes result from the process of cooling and airing are due to the airing, and that the cooling of eggs during the process of incubation below the proper incubating temperature, when considered by itself, is detrimental.

\section{THE USE OF MOISTURE DURING THE INCUBATION OF HEN EGGS.}

Egg shells are porous, and during incubation moisture and carbon dioxide are given off, thus leaving the eggs lighter in weight. The amount of moisture that leaves eggs during artificial incubation can be controlled by regulating the humidity of the air in the incubating chamber. How much moisture should eggs lose for best results? Or in other words, how much should eggs decrease in weight during incubation in order to obtain best hatches and have the chicks most thrifty and vigorous?

In natural incubation the normal loss in weight is shown 
in the following table taken from bulletin No. 98, of the West Virginia Experiment Station.

Table showing normal loss in weight of 100 eggs in ounces for the first nineteen days of incubation.

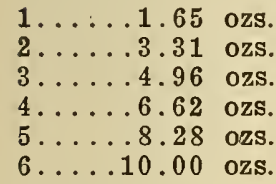

$1 \ldots . .65$ ozs.

$2 \ldots \ldots 3.31$ ozs.

$3 \ldots \ldots 4.96$ ozs.

$6 \ldots .10 .00$ ozs.

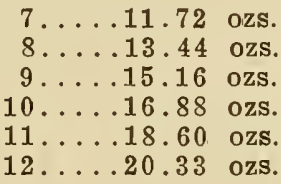

$13 \ldots .22 .10$ ozs.

$14 \ldots .23 .88$ ozs.

$15 \ldots .25 .66$ ozs.

$16 \ldots 27.44$ ozs.

$17 \ldots 29.21$ ozs.

$18 \ldots . .30 .99$ ozs.

$19 \ldots .32 .77$ ozs.

The following tests have been made to determine whether variations in the humidity of the air in the incubating chamber, with its consequent influence upon the loss in weight of eggs, has any influence upon the vigor of the resulting chickens.

\section{TEST 1.}

Incubator started September 21, 1907

\begin{tabular}{|c|c|}
\hline $\begin{array}{c}\text { CYPHERS No. } 3 \\
\text { MOISTURE } \\
\text { 336 sq. in. wet sand ex- } \\
\text { posed from start to } \\
\text { finish, under egg trays. }\end{array}$ & $\begin{array}{l}\text { CYPHERS No. } 3 \\
\text { No MOISTURE } \\
\text { Operated according } \\
\text { to directions of } \\
\text { manuficturer. }\end{array}$ \\
\hline Number of eggs.... & 240 \\
\hline Weight of eggs at start. & $29.82 \mathrm{lbs}$. \\
\hline Loss in weight in 17 days. & $4.32 \mathrm{lbs}$. \\
\hline Normal loss as calculated from table. . 4.38 Ibs. & $4.38 \mathrm{lbs}$. \\
\hline Tested out on 17 th day... & 27 eggs. \\
\hline Number of chicks.... & 182 \\
\hline Percentage hatch "fertile" eggs. . & 85.4 \\
\hline Weight of 100 chicks ......... 8.17 lbs. & $7.32 \mathrm{lbs}$. \\
\hline Number of chicks died in 25 days. . 30 & 22 \\
\hline Per cent hatch of all eggs incubated. . 68.7 & 75.8 \\
\hline
\end{tabular}

\section{TEST 2.}

Incubator started January 19, 1908. Eggs similar in both incubators. 
Incubators used,

$$
\text { Cyphers (1906) }
$$

No Moisture

Number of eggs...............360

Original weight of eggs......... $44.60 \mathrm{lbs}$.

Feb. 7 th. weight of eggs....... 37.65 libs.

Loss in 19 days ............ $6.95 \mathrm{lbs}$.

Calculated normal loss......... $7.37 \mathrm{lbs}$.

Departure from normal......... .42 Ibs.

Result of hatch.

Cracked in turning............ 5

Number of chicks.............252

Percentage hatch of all eggs incu-

bated except those cracked...... 70.9

Weight of chicks when removed from

incubator, per hundred........ $7.9 \mathrm{lbs}$.
Prairie State, (Sand Tray) Moisture. 360

$44.38 \mathrm{lbs}$. $39.65 \mathrm{Ibs}$. $4.73 \mathrm{lbs}$. $7.37 \mathrm{lbs}$. $2.64 \mathrm{lbs}$. 244

68.5

$8.5 \mathrm{lbs}$.

\section{Treatment of Chicks.}

Marked and placed in two of Rices' Gasoline broodersOne-half of chicks from each incubator in each brooder.

Total deaths until

BROODER NO. 1 Cyphers

March 24, chicks

24 days old .....2

Weight of 100 chicks

from brooder No. 1, 24

days old.......... Cyphers 26.2 lbs. Prairie State, 26.3 lbs. (Chicks injured in brooder no. 2 by accidental escape of gases from gasoline flame into space under hover).

\section{TEST 3.}

Incubator started March 2, 1908.

Eggs similar in both incubators.

Incubators used.

No moisture. Cyphers (1906).

Number of eggs incubated........360

Original weight of eggs........ 48.27 lbs.

Weight of eggs March $17 \ldots \ldots \ldots 42.88 \mathrm{lbs}$.

Loss in weight in 15 days....... $5.39 \mathrm{lbs}$.

Calculated normal loss......... 5.77 lbs.

Departure from normal.......... .38 lbs.
Moisture. Prairie State (Sand tray) 360 $48.08 \mathrm{lbs}$. $44.05 \mathrm{lbs}$. $4.03 \mathrm{lbs}$. $5.77 \mathrm{lbs}$. 1. 74 Ibs. 
Result of hatch.

No. moisture.

Moisture.

Cracked in turning........... 5 eggs

Tested out on March 17 th.......6. 69 eggs

Number of chicks.............243

Percentage hatch of all eggs incu-

bated except those cracked.......68.4

Weight of chicks per hundred..... $8.75 \mathrm{lbs}$.

5 eggs

57 eggs

266

74.9

9. $11 \mathrm{lbs}$.

Toe marked and placed in two brooders.

Deaths from all causes during

first 31 days.............. 39

TEST 4.

Incubators started March 29, 1908.

Incubators used.

No moisture. Cyphers (1906).

Number of eggs incubated........360

Original weight of eggs........ 46.88

Weight of eggs April $13 \ldots \ldots \ldots \ldots 41.20$

Loss in weight in 15 days........ $5.681 \mathrm{bs}$.

Calculated normal loss......... $5.77 \mathrm{lbs}$.

Departure from normal.......... .0. $09 \mathrm{lbs}$.

Result of hatch.

Cracked in turning............ 2 eggs

Tested out on 15 th day......... 52 eggs

Number of chicks..............273

Percentage hatch of all eggs incubated except those cracked...... 76.2

Weight of chicks per hundred when removed from incubator........ 8.56 lbs.

Died from all causes during

first 32 days.............. 28

Weight of chicks per hundred May

1 st, 32 days old............ 35.96

Moisture.

Prairie State.

(Sand tray)

360

47.02

42.97

$4.05 \mathrm{lbs}$.

$5.77 \mathrm{lbs}$.

1. $72 \mathrm{lbs}$.

$\begin{array}{rr}5 & \text { eggs } \\ 59 & \text { eggs } \\ 269 & \end{array}$

75.7

9.92 lbs.

79

35.87

\section{TEST 5.}

Incubators started Marck, 16, 1908.

Eggs similar in both incubators.

Incubators used.

No moisture. Cyphers (1906)

Number of eggs incubated........ 360

Original weight of eggs........4 $48.02 \mathrm{lbs}$.

Moisture.

Cyphers with moisture pan. 360

$48.02 \mathrm{lbs}$. 
Weight of eggs per hundred...... 13.33 lbs.

Weight of eggs March $31 \ldots \ldots \ldots 42.70 \mathrm{lbs}$.

Loss in weight in 15 days....... $5.32 \mathrm{lbs}$.

Calculated normal loss......... 5.77 lbs.

Departure from normal......... .45 lbs.

$13.33 \mathrm{lbs}$.

44.75 Ibs.

$3.27 \mathrm{lbs}$.

$5.77 \mathrm{lbs}$

$2.50 \mathrm{lbs}$.

Result of hatch.

Cracked in turning........... 5

Tested out April 1.........662

8

64

Number of chicks............237

218

Percentage hatch of all eggs incu-

bated except those cracked in

turning $\ldots \ldots \ldots \ldots \ldots \ldots 6.7 \%$

Weight of chicks per hundred when

recovered from incubator....... 9.00 lbs.

Weight of chicks May 21 per hundred 57.46 lbs.

Death from all causes to May $21 \ldots .86$

7.46 lbs. $\quad 63.09 \mathrm{lbs}$

54

TEST 6.

Incubators started Apri7. 11, 1908.

Incubators used.

Cyphers

No moisture.

Number of eggs incubated........ 360

Original weight of eggs........ $47.05 \mathrm{lbs}$.

Weight of eggs April 27th....... 41.05 lbs.

Loss in weight in 16 days........ $6.00 \mathrm{lbs}$.

Calculated normal loss......... 6.17 lbs.

Departure from normal......... .17 lbs.

Cyphers

Moisture.

360

$46.98 \mathrm{lbs}$.

$43.10 \mathrm{lbs}$.

$3.88 \mathrm{lbs}$.

$6.17 \mathrm{lbs}$.

$2.29 \mathrm{lbs}$.

Result of hatch.

Cracked in turning............. 8

Tested out on 16th day........440

Number of chicks............289

255

Percentage hatch of all eggs

incubated except those cracked

in turning.............. 82.1

Weight of chicks per hundred

when removed from incubator... $8.22 \mathrm{lbs}$.

Died from all causes during

first 52 days............ 70 chicks

Weight of chicks per hundred

when 52 days old.......... $52.21 \mathrm{lbs}$.

71.6

$8.89 \mathrm{lbs}$.

50 chicks

$46.97 \mathrm{lbs}$. 


\section{TEST 7.}

Incubators started May 8, 1908.

Incubators used.

Number of eggs incubated............. 360

Weight of 360 eggs.......... $45.851 \mathrm{bs}$.

Weight of eggs May $23 \mathrm{rd} \ldots \ldots \ldots \ldots 40.47 \mathrm{lbs}$.

Loss in weight in 15 days........ $5.381 \mathrm{bs}$.

Calculated normal loss.......... $5.77 \mathrm{lbs}$.

Departure from normal......... . 39 !bs. Result of hatch.

Cracked in turning............ 2 eggs.

Tested out on 15 th day......... 59 eggs.

Number of chicks..............268

Percentage hatched of all eggs incu-

bated except those cracked...... 74.8

Weight of chicks per hundred when removed from incubator........ $8.73 \mathrm{lbs}$.

Died during first 27 days........ 52

Weight of chicks 27 days old, per hundred.............21.86 1bs.
Cyphers

Moisture pans. 360

$45.821 \mathrm{bs}$.

$42.50 \mathrm{lbs}$.

$3.32 \mathrm{lbs}$.

$5.77 \mathrm{lbs}$.

2.45 lbs.

11 eggs.

54 eggs.

259

74.2

$8.86 \mathrm{lbs}$. 48

$22.74 \mathrm{lbs}$.

\section{TEST 8.}

Incubators started May 8, 1908

Incubators used

Cyphers

No moisture.

Number of eggs Incubated........360

Weight of eggs............. $46.15 \mathrm{lbs}$.

Weight of eggs May 23rd.........440.70 Jbs.

Loss in weight in 15 days........ $5.45 \mathrm{lbs}$.

Calculated normal loss.......... $5.77 \mathrm{lbs}$.

Departure from normal........... . $32 \mathrm{lbs}$.

Result of hatch.

Cracked in turning ............ 3 eggs.

Tested out on 15 th day.........6 60

Number of chicks............268

Percentage hatched of all eggs incu-

bated except those cracked ...... 75.0

Weight of chicks per hundred when

removed from incubator....... $8.58 \mathrm{lbs}$.

Weight of chicks when 27 days old

Died during first 27 days......... 91

per hundred ............21.14 lbs.
Prairie State

Sand tray

Moisture.

360

$46.13 \mathrm{lbs}$.

$42.60 \mathrm{lbs}$.

$3.53 \mathrm{lbs}$.

$5.77 \mathrm{lbs}$.

$2.24 \mathrm{lbs}$.

61

5 eggs.

267

75.2

9. $06 \mathrm{lbs}$.

$22.771 \mathrm{bs}$ 
The following table summarizes the results of the eight tests.

No moisture used

in incubator

Number of eggs incubated.......2860

Number of chicks hatched........2012

Total loss in weight of eggs..... 44.49 lbs.

Normal loss as calculated........ $46.77 \mathrm{lbs}$.

Departure from normal loss of weight $2.28 \mathrm{lbs}$.

Average weight of chicks per hundred

when removed from incubator....

Average weight of chicks per hun-

dred at second weighing....... $35.7 \mathrm{lbs}$.

Total number of deaths from all

causes ................ 415

Per cent died of all hatched...... 20.6
Moisture used in incubator 2860 1943

$29.41 \mathrm{lbs}$. $46.77 \mathrm{lbs}$. $17.36 \mathrm{lbs}$.

8.79 lbs. 36.2 lbs.

20.6

\section{RESULTS OF THE TEST.}

1. In these experiments somewhat more chicks were hatched in the incubators operated without moisture. It is possible, however, that this result may have been due to the operator's more extensive experience in the use of the no-moisture machines, rather than to any injury resulting from the use of moisture.

2. Under the conditions which obtained in these experiments the actual loss in weight of the eggs incubated without added moisture was very nearly normal. while in the case of machines operated with moisture the loss was only about twothirds of the normal, and yet in spite of this fact there was very little difference in the number of chicks hatched out under the two treatments.

3. In all cases the chicks hatched in the machines with added moisture were heavier when hatched than the chicks hatched without added moisture, and apparently they remained somewhat heavier, for at the second weighing when the chicks were two or three weeks old they averaged one-half pound per hundred chicks heavier than the chicks hatched without moisture.

4. The percentage of deaths from all causes in the case 
of the two lots of chickens was exactly the same. Most of the deaths seemed to be due to white diarrhoea or other digestive disturbances.

5. The results of this work seem to indicate that the chick embryos have the power to adapt themselves, to a considerable extent to different degrees of humidity during their development, and consequently to slightly differing percentages of moisture in the tissues of their bodies. The chicks with the lower moisture content seemed to be as vigorous as those containing more moisture, but there are certain limits beyond which this would not be true, and undoubtedly it is the best practice to incubate eggs so that the loss in weight will agree as closely as possible with the normal. 


.

